\title{
POTENTIAL FUNGICIDES AND PLANT EXTRACTS AGAINST FUSARIAL WILT OF BRINJAL
}

\author{
M.A. BASHAR*, Romana AKTer AND K.S. HoSSAin ${ }^{1}$ \\ Department of Botany, University of Dhaka, Dhaka-1000, Bangladesh
}

Key words: Fungicide, Plant extract, Brinjal, Fusarial wilt

\begin{abstract}
Antifungal potentials of nine fungicides and eight plant parts extracts were tested in opposition to Fusarium oxysporum Schlecht. and F. solani (Mart.) Sacc. the two pathogens, isolated from wilted roots of brinjal plants. Efficiency gradients observed in the present study expressed that Bavistin and Tall were the best inhibiting agent against the in vitro growth of the test pathogenic fungi. Among aqueous extracts of eight plant parts significant inhibition of the growth of the pathogens was observed with Azadiracta indica (leaf), Zingiber officinale (rhizome) and Asparagus racemosus (root) at 20\% concentration.
\end{abstract}

Brinjal (Solanum melongena L.) is an important vegetable of Bangladesh and is more or less available round the year. It suffers from more than 20 different diseases, of which fusarial wilt is the most destructive one throughout the world ${ }^{(1,2)}$. The pathogens are mainly soil borne and presently being used to control by various physical, chemical, biological and cultural methods. Various workers in different countries of the world evaluated the efficacy of various fungicides and plant extracts against Fusarium spp. under laboratory and field conditions ${ }^{(3-7)}$. In Bangladesh research information on the control measures of the fusarial wilt of brinjal is insufficient ${ }^{(8)}$.

Fusarium oxysporum Schlecht. and F. solani (Mart.) Sacc.- the two pathogens were isolated from wilted roots of brinjal plants following Blotter and Agar plate methods ${ }^{(9)}$. Identities of the pathogens were determined following the standard literature(10). The pathogenicity of the pathogens was confirmed by inoculating on seedling of the selected cultivar.

Nine fungicides with 7 different active ingredient(s), were collected from local market of the Dhaka city (Table 1). Amongst the nine fungicides used in the present investigation, Bavistin, Mancozeb and Dithane M are systemic while Mc sulphur, Tall, Limisulpher and Salcox are protectant and Ridomil gold MZ is both systematic and protectant. Fungitoxicity of these nine fungicides at $400 \mathrm{ppm}$ concentration was evaluated against the two test pathogens following poison food technique ${ }^{(11)}$. The radial growth of the colonies was measured at the 5 th day of incubation.

*Author for correspondence: < botanybashar@yahoo.com>. ${ }^{1}$ Department of Botany, Jagannath University, Dhaka, Bangladesh. 
Plant parts viz. leaves, roots, bulbs or rhizomes of eight plants were collected from the Botanical Garden of Curzon Hall of Dhaka University Campus and New Market, Dhaka for evaluating their fungi toxic potentiality on the vegetative growth of the test pathogens (Table 2). Aqueous plant extracts were prepared following the method of Yasmin et al.(12). The radial growth of the colonies was measured at the 7 th day of incubation.

Table 1. Potentiality of fungicides against the radial growth of Fusarium solani and F. oxysporum at $400 \mathrm{ppm}$.

\begin{tabular}{lcc}
\hline Name of fungicides & \multicolumn{2}{c}{ \% inhibition of the test fungi } \\
\cline { 2 - 3 } [Active ingredient(s)] & F. solani & F. oxysporum \\
\hline Bavistin 50 WP [50\% Carbendazim] & $100^{\mathrm{a}}$ & $92.98^{\mathrm{a}}$ \\
Dithane M-45 [80\% Mancozeb] & $76.93^{\mathrm{a}}$ & $71.35^{\mathrm{b}}$ \\
Limisulpher 80 WP [80\% Sulphur] & $68.78^{\mathrm{a}}$ & $74.65^{\mathrm{b}}$ \\
Mancozeb 80 WP [80\% Mancozeb] & $54.48^{\mathrm{b}}$ & $53.99 \mathrm{~b}$ \\
Mc sulphur 80 WP [50\% sulpher] & $46.32^{\mathrm{b}}$ & $38.98^{\mathrm{b}}$ \\
Oxyvit 50 WP [Cupper oxochloride] & $78.36^{\mathrm{a}}$ & $32.55^{\mathrm{b}}$ \\
Ridomil gold MZ 68 WP [64\% mancozeb and 4\% metalaxyl] & $41.63^{\mathrm{a}}$ & $58.48^{\mathrm{b}}$ \\
Salcox 50 WP [50\% cupper oxichloride] & $38.16^{\mathrm{b}}$ & $27.00^{\mathrm{c}}$ \\
Tall 25 EC [25\% Propiconazole] & $93.23^{\mathrm{a}}$ & $100^{\mathrm{a}}$ \\
\hline Com
\end{tabular}

Comments: Efficiency gradient against Fusarium solani is Bavistin $>$ Tall $>$ Oxyvit $>$ Dithane $>$ Limisulpher $>$ Mancozeb $>$ Mc sulphur $>$ Ridomil and Salcox. and against F. oxysporum is Tall $>$ Bavistin $>$ Limisulphur $>$ Dithane $>$ Ridomil $>$ Mancozeb $>$ Mc sulphur $>$ Oxyvit and Salcox.

$\mathrm{a}, \mathrm{b}$ and $\mathrm{c}$ indicate significance at $\mathrm{p}=0.001,0.01$ and 0.05 , respectively.

For both the cases per cent growth inhibition of each test fungus was calculated following the formula of Yasmin et al.(12). Three replications were maintained and inoculated plates were incubated at $25 \pm 2^{\circ} \mathrm{C}$ in each case. The results were statistically analyzed by ' $t$ ' test following Steel and Torrie ${ }^{(13)}$.

In the Petri plates, all the fungicides causes partial or complete inhibition of Fusarium solani and F. oxysporum at $400 \mathrm{ppm}$ concentration (Table 1). The complete inhibition of the growth of $F$. solani was observed with Bavistin followed by Tall (93.23\%), Oxyvit (78.36\%), Dithane M (76.93\%), Limisulpher (68.78\%), Mancozeb (54.48\%), Mc Sulphur (46.32\%), Ridomil gold MZ (41.63\%) and Salcox (38.16\%), respectively.

In 2014, it was reported that Mancozeb inhibit mycelial growth of Fusarium solani, the causal agent of coriander rot, completely at 2500 ppm whereas inhibition were only 85.27 and $79.25 \%$ by Propiconazole (active ingredient of Tall) and copper oxychloride (active ingredient of Salcox and Oxyvit), respectively ${ }^{(14)}$. 
In the present investigation, growth of Fusarium oxysporum was completely inhibited with Tall at 400 ppm. Bavistin, Limisulpher, Dithane - M, Ridomil gold MZ, Mancozeb, Mc sulphur, Oxyvit, and Salcox were responsible for 92.98, 74.65, 71.35, 58.48, 53.99, $38.98,32.55$ and $27.00 \%$ growth inhibition of F. oxysporum, respectively at the same concentration (Table 1). Jatav et al. (2013)(5) while reporting the results of laboratory evaluation of six fungicides on F. oxysporum f. sp. melongenae causing wilt of brinjal found that Bavistin, Ridomil and Diathen M were inhibited 90.00, 44.26 and $45.76 \%$ growth of the pathogen, respectively at $500 \mathrm{ppm}$.

Efficiency gradients observed in the present study expressed that Bavistin, Tall, Dithane M-45 and Ridomil gold MZ were the best inhibiting agent against the in vitro growth of the test pathogenic fungi. The differences between these reports and the present study might be owing to the difference in strains of the causal organism.

Table 2. Effect of plant extracts at different concentrations on the radial growth of Fusarium oxysporum (FO) and Fusarium solani (FS).

\begin{tabular}{|c|c|c|c|c|c|c|}
\hline \multirow{3}{*}{ Name of plant (used plant part) } & \multicolumn{6}{|c|}{$\%$ inhibition at different concentration (\%) } \\
\hline & \multicolumn{2}{|c|}{5} & \multicolumn{2}{|c|}{10} & \multicolumn{2}{|c|}{20} \\
\hline & $\mathrm{FO}$ & FS & $\mathrm{FO}$ & FS & $\mathrm{FO}$ & FS \\
\hline Adhatoda vasica Nees (Leaf) & $29.82^{b}$ & $33.94^{\mathrm{a}}$ & $54.58^{\mathrm{b}}$ & $58.48^{\mathrm{a}}$ & $71.35^{\mathrm{a}}$ & $79.33^{a}$ \\
\hline Allium cepa L. (Bulb) & $20.85^{c}$ & $23.97^{b}$ & $41.52^{\mathrm{b}}$ & $44.83^{\mathrm{a}}$ & $66.86^{\mathrm{a}}$ & $72.70^{a}$ \\
\hline Allium sativum L. (Bulb) & $28.46^{\mathrm{b}}$ & $33.13^{a}$ & $50.68^{\mathrm{b}}$ & $59.84^{\mathrm{a}}$ & $74.66 a$ & $81.87^{a}$ \\
\hline Asparagus racemosus L. (Root) & $64.20^{\mathrm{a}}$ & $64.00^{\mathrm{a}}$ & $75.39^{a}$ & $71.00^{\mathrm{b}}$ & $93.85^{\mathrm{a}}$ & $91.10^{a}$ \\
\hline Azadirachta indica A Juss (Leaf) & $58.00^{\mathrm{a}}$ & $40.00^{\mathrm{b}}$ & $73.42^{\mathrm{a}}$ & $77.11^{\mathrm{a}}$ & $95.50^{a}$ & $96.00^{\circ}$ \\
\hline Cassia alata L. (Leaf) & $40.26^{\mathrm{a}}$ & $35.00^{\mathrm{b}}$ & $58.10^{\mathrm{a}}$ & $66.66^{\mathrm{a}}$ & $86.57^{a}$ & $86.00^{a}$ \\
\hline Ocimum sanctum L. (Leaf) & $18.12^{\mathrm{c}}$ & $22.02^{\mathrm{b}}$ & $40.00^{\mathrm{b}}$ & $43.46^{\mathrm{a}}$ & $66.27^{b}$ & 73.29 \\
\hline Zingiber officinale Rosc. (Rhizome) & $67.11^{\mathrm{a}}$ & $54.00^{\mathrm{a}}$ & $76.06^{\mathrm{a}}$ & $71.00^{\mathrm{a}}$ & $94.85^{\mathrm{a}}$ & $93.00^{\mathrm{a}}$ \\
\hline
\end{tabular}

$\mathrm{a}, \mathrm{b}$ and ${ }^{\mathrm{c}}$ indicate significance at $\mathrm{p}=0.001,0.01$ and 0.05 , respectively.

Results of plant extracts on the radial growth of Fusarium solani is presented in Table 2. All the plant extracts showed varied degree of growth inhibition of the pathogen at different concentrations. Out of the eight plant extracts, Azadiracta indica showed 96\% radial growth inhibition of the pathogen at $20 \%$ concentration which was followed by Zingiber officinale (93\%) and Asparagus racemosus (91.10\%). The inhibition of the pathogen increases with the increase of the concentration of the plant extracts in culturte medium.

The order of effectiveness against $F$. solani at $20 \%$ concentration was Azadiracta indica $(96 \%)>$ Zingiber officinale $(93 \%)>$ Asparagus racemosus $(91.10 \%)>$ Cassia alata $(86 \%)>$ Allium sativum $(81.87 \%)>$ Adhatoda vasica $(79.33 \%)>$ Ocimum sanctum $(73.29 \%)>$ A. cepa (72.70\%) (Table 2). 
The highest (95.50\%) inhibition of the growth of Fusarium oxysporum was observed with Azadiracta indica at $20 \%$ concentration which was followed by Zingiber officinale (94.85\%) and Asparagus racemosus (93.85\%). The inhibition of the pathogen increases with the increase of the concentration of the treatments (Table 2). The order of effectiveness against F. oxysporum at $20 \%$ concentration was Azadiracta indica $(95.50 \%)>$ Zingiber officinale $(94.85 \%)>$ Asparagus racemosus $(93.85 \%)>$ Cassia alata $(86.57 \%)>$ Allium sativum $(74.66 \%)>$ Adhatoda vasica $(71.35 \%)>$ Allium cepa $(66.86 \%)>$ Ocimum sanctum $(66.27 \%)$.

Plant parts and their constituents of some higher plants have already been reported to be of successful nature of fungitoxicants because of their lesser phytotoxicity, systemicity, easily biodegradability and favourable effects for the growth of the host ${ }^{(3,4)}$. Antifungal potentiality of different plant extract have been reported earlier by several investigators. Joseph et al.(3) reported that leaf extracts of Azardiachta indica at $20 \%$ concentration was found most effective (53.22\%) against Fusarium solani f. sp. melongenae and Ocimum sanctum arrested $38.38 \%$ growth of the pathogen at same concentration.

Out of seven aqueous extracts of plant parts, Datura metel and Cassia alata and Azadiracta indica were found most efficient inhibitor of Fusarium solani and F. oxysporum, the causative agent of brinjal wilt by Bashar and Chakma(8).

Chakraborty et al.(15) reported the efficacy of various cell free extracts of the plants against the growth inhibition of the pathogen. The effectiveness of extracts varied significantly with dosage, where $100 \%$ inhibition of the pathogen was achieved both with Azadiracta indica and Allium sativum extracts.

\section{References}

1. Dwivedi1 SK and Enespa1 2013. Studies on Fusarial wilt pathogen of two vegetable crop fields with emphasis on physico-chemical properties. Intl. J. Agron. Plant. Prod. 4(9): 2130-2137.

2. Rahman MA, F Ali, KMA Hossain and L Laila 2011. Screening of different eggplant cultivars against wilt disease caused by fungi, bacteria and nematodes. J. Exp. Sci. 2(1): 6-10.

3. Joseph B, MA Dar and V Kumar 2008. Bioefficacy of plant extracts to control Fusarium oxysporium f. sp. melongenae incitant of brinjal wilt. Global J. Biotech. Biochem. 3(2): 56-59.

4. Bhadauria BP, Y Singh, S Puri and PK Singh 2012. Ecofriendly management of Fusarium wilt of brinjal. Ecology, Environment and Conservation Paper 18(4): 1049-1052.

5. Jatav NK, KS Shekhawat and LP Balai 2013. Chemical control of wilt of brinjal (Solanum melongena L.) caused by Fusarium oxysporium f. sp. melongenae (Schlecht) Mutuo and Ishigami. Trends in Biosciences 6(6): 781-783.

6. Safikhani N, B Morid and RH Zamanizadeh 2013. First report of Fusarium wilt of eggplant caused by Fusarium oxysporium f. sp. melongenae in Iran. New Disease Reports 28: 16.

7. Parsa S, ST Sahi, A Jabbar, A Rehman, K Riaz and A Hannan 2013. Chemical and biological management of Fusarium oxysporium f. sp. melongenae. Pak. J. Phytopathol. 25(2). 155-159.

8. Bashar MA and M Chakma 2014. In vitro control of Fusarium solani and F. oxysporum the causative agent of brinjal wilt. Dhaka Univ. J. Biol. Sci. 23(1): 53-60. 
9. Aneja, KR 2003. Experiments in Microbiology, Plant Pathology and Biotechnology. $4^{\text {th }}$ ed., New Age Publishers, New Delhi. pp. 607.

10. Booth C. 1971. The genus Fusarium. Commonwealth Mycological Institute, Kew, Surrey, England. pp. 237.

11. Rajani P, V Sridevi, MVVC Lakshmi and SPK Kumari 2012. Inhibitory effect of aqueous plant extracts on the growth of aflatoxin producing Aspergillus parasiticus. Int. J. Eng. Sci. Adv. Tech. 2(2): 365-371.

12. Yasmin M, KS Hossain and MA Bashar 2008. Effects of some angiospermic plant extracts on in vitro vegetative growth of Fusarium moniliforme. Bangladesh J. Bot. 37(1): 85-88.

13. Steel RGD and JH Torrie 1960. Principles and Procedures of Statistics. McGraw Hill Book Co., New York. pp. 481.

14. Bhaliya CM and KB Jadeja 2014. Efficacy of different fungicides against Fusarium solani causing coriander rot. The Bioscan. 9(3): 1225-1227.

15. Chakraborty MR, NC Chatterjee and TH Quimio 2009. Integrated management of fusarial wilt of eggplant (Solanum melongena) with soil solarization. Micologia Aplicada International 21(1): 25-36.

(Manuscript received on 3 May, 2015; revised on 10 June, 2015) 